\title{
THE EPITAXY OF GOLD
}

\author{
Richard W. Vook and Baybars Oral \\ Laboratory for Solid State Science and Technology, Physics Department, Syracuse \\ University, Syracuse, New York, U.S.A.
}

\begin{abstract}
Previous studies of the epitaxial growth of gold by vapor deposition on a variety of substrates have been compiled and listed according to the type of sulsstrate.

A short introduction describing the epitaxy process has been included for general reference purposes and some highly promising applications of thin film technology are discussed.
\end{abstract}

\section{Introduction}

Epitaxy, in the usual sense of the word, is a term that refers to the oriented growth of one material, the overgrowth, on a crystalline substrate. The orientation relationships are such that the $\{\mathrm{HKL}\}$ plane of the overgrowth is parallel to the $\{h k l\}$ plane of the monocrystalline substrate. Correspondingly the <UVW > and <uvw> directions are parallel. The relationships are usually written as follows: $\{\mathrm{HKL}\}$ $/ /\{h k l\}$ and $<U V W>/ /<u v w>$. Exactly what those relationships are can often be predicted on the basis of lattice fitting or lattice misfit type arguments. Thus, those planes and directions which give the best lattice fit generally determine the orientation of the film with respect to the substrate. The misfit that occurs produces strain, which, if large enough, may generate line defects called misfit dislocations at the interface between the film and the substrate. These dislocations tend to reduce the misfit strain. The theoretical basis for this result will be outlined in a subsequent section.

Investigations of epitaxial growth phenomena are an important segment of thin film studies. The processes that are involved in forming an epitaxial overgrowth may involve the solid, liquid, and vapor states. Thus, the growth of solid phases in alloys may involve interfacial epitaxial relationships. In the liquid state one can form epitaxial overgrowths by electrodeposition or by a process called liquid phase epitaxy (LPE), whereby a saturated solution plates out a material on a particular solid substrate.
Vapor phase methods are probably the most popular and include:

- Vacuum evaporation from a hot source onto a colder substrate (nowadays more popularly called molecular beam epitaxy - MBE),

- Chemical vapor deposition (CVD), which involves surface chemical reactions of gases at pressures usually not too different from atmospheric (e.g. thermal decomposition of gas on a hot substrate or polymerization of monomers), and

- Ion sputtering processes whereby ions produced in a gas discharge (or by other gaseous ionization methods) are accelerated towards a target. The subsequent interaction by momentum interchange results in the emission of atoms or molecules from the target material which then are permitted to strike a substrate on which the film of interest grows.

Several other methods also have been employed to form thin films but these are not as useful in epitaxy studies as the ones described above.

The properties of epitaxial films can be made to vary widely because of the high reactivity of individual atoms and molecules. Thus in combining the atoms to form a thin film, numerous physical and chemical processes may be involved, thereby making possible an almost limitless variety of properties, for example, microstructure (i.e. defect content), orientation, composition, and topography. This result is especially true for very thin films. In this case their 
physical, chemical, and mechanical properties may be widely different from those of either the bulk material or the substrate.

Recent studies on surface catalytic reactions, for example, show that the catalytic reactivity of thin epitaxial films, approximately one monoatomic layer thick, formed on particular metal substrates may significantly increase the reactivity of the surface for a particular chemical reaction. Typical examples are $\mathrm{Au}$ on $\mathrm{Pt}(1)$, and $\mathrm{Cu}$ on $\mathrm{Ru}(2)$. Since bulk gold and bulk copper are normally quite unreactive in the cases in question, this result is very surprising. Clearly the reverse effect, namely the reduction of surface reactivity by a more reactive thin film material, should also be possible with enormous implications in the field of corrosion. Thus by using thin film techniques, one can devise an almost limitless range of new material surfaces, each of which having its own distinct surface chemistry.

In the case of electrical properties, it has been shown that an infinite variety of band structures can be prepared by making periodic, thin layers of films and stacking them on top of each other. These so-called 'strained-layer-superlattices' (formed by MBE) provide the semiconductor industry with the opportunity to tailor-make particular microelectronic devices that simply would not be possible us- ing only bulk materials (3). As a consequence the range of possible microelectronic devices has been enormously extended.

Epitaxial growth of thin films will allow the current more or less planar integration, common in microelectronic devices, to be extended into three dimensions, thereby reducing the space needed for the associated devices. To accomplish this task one needs to be able to grow epitaxial metal and especially insulator films on silicon (or, in general, on other semiconducting substrates, such as GaAs) as well as epitaxial silicon layers on epitaxial insulator substrates. Great efforts are currently being expended to form these epitaxial $\mathrm{Si} /$ insulator/Si/insulator/Si... multilayers with the degree of perfection that is required.

These few illustrations show that epitaxy studies represent not only interesting science but also have enormously important applications in industry, especially in the areas of microelectronics, catalysis and corrosion.

The present paper reviews the work that has been reported on the epitaxial growth of gold films formed on a

Fig. 1 Schematic illustration of the basic thin film growth modes: (a) layer (FVM), (b) layer by layer, (c) layer plus island (SK), (d) island (vW).
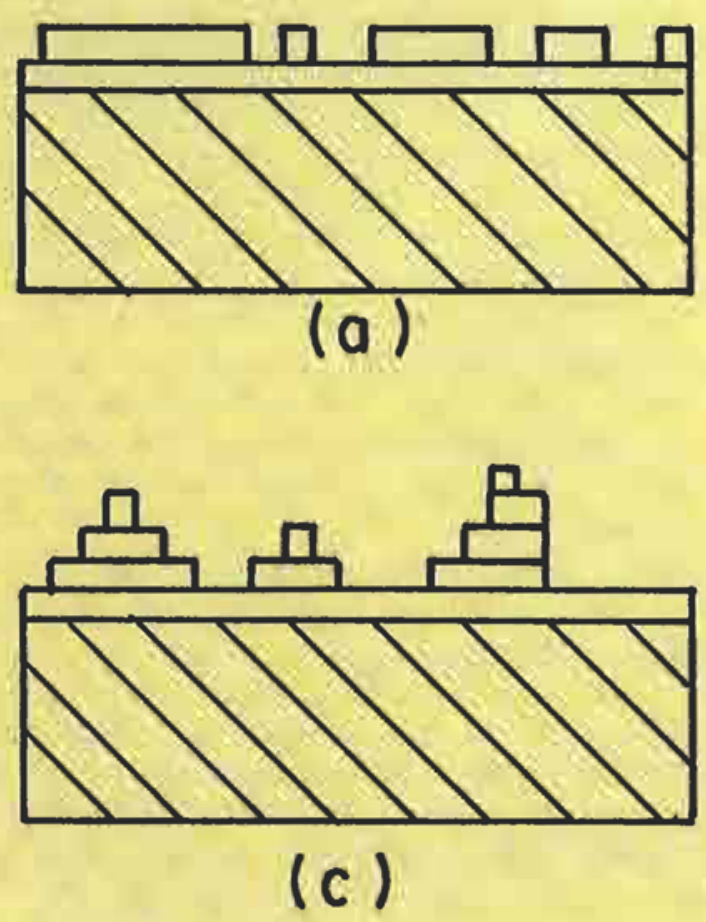
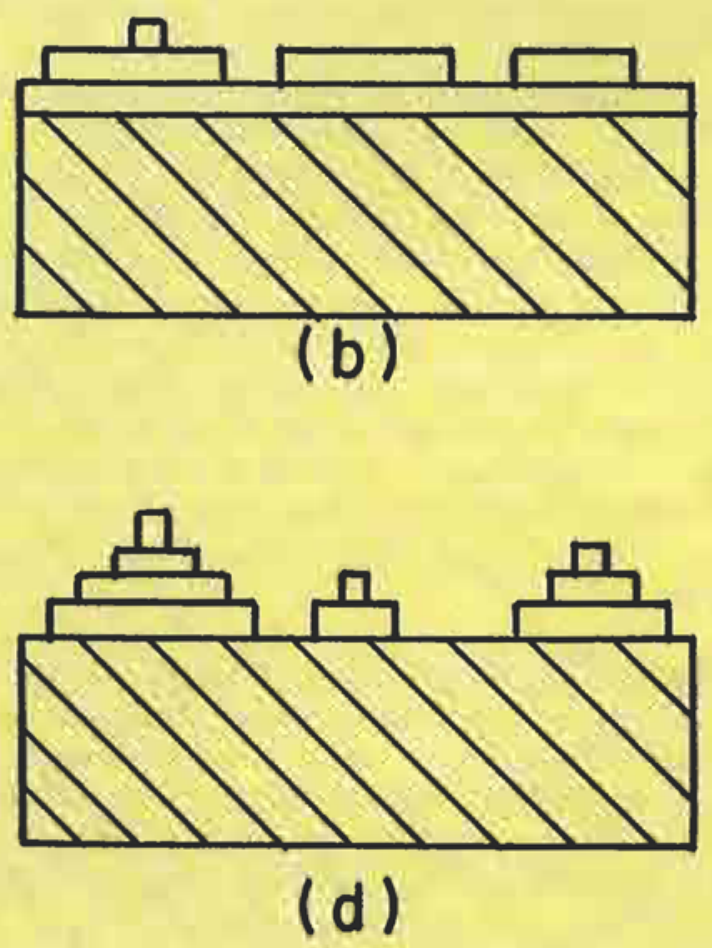
variety of substrates. A listing of sources is presented in a series of tables that are up-to-date through early 1986. This work builds on two previous reviews published in the early 1970 s $(4,5)$. The current compilation should serve as a useful reference for previous studies on the epitaxy of gold films.

\section{Epitaxial Film Growth Modes}

The formation of a thin film by any of the experimental methods mentioned earlier is not a simple process. Generally atoms or molecules which are incident on a surface may either diffuse over the surface, diffuse into the bulk of the substrate, or be desorbed. In the latter case no film forms. In typical cases one or more of these processes dominates the film formation process. Au films, for example, deposited on most substrates at temperatures at least within $100 \mathrm{~K}$ and $1000 \mathrm{~K}$, surface or bulk diffuse before they become bound to their final resting place. Desorption is negligible and films form easily.

The growth mode of a film, however, falls into one of three basic categories:

- Layer (Frank and van der Merwe (6): FVM),

- Layer plus island (Stranski-Krastanov (7): SK), and

- Island (Volmer-Weber (8): VW).

These growth modes are illustrated in Figure 1, which also shows a modification of the layer mode called 'layer-bylayer' (Figure 1b). In this latter case the $(n+1)$ th layer starts growing before the $n$th layer is complete. Thus normal layer growth means that monoatomic layers form on top of each other, one at a time. In this case, incident atoms surface diffuse until they find a step where they attach themselves, thereby extending the step. Clearly, surface imperfections and impurities may have a drastic effect on this crucial surface diffusion process.

In the SK growth mode, one or several layers form first. Then island nuclei form and grow on top of the initial layers. In the VW mode, island nuclei form initially on the substrate, increasing their density and sizes as deposition continues until they coalesce. Further deposition results in a completely continuous film that may eventually become quite flat. On this flat, thick film surface, further film growth by a layer mode may occur.

Thermodynamic considerations (for a recent review see Reference 9), modified by supersaturation considerations have been used to predict the growth mode in particular cases. The theory is based largely on surface and interfacial energy considerations. The surface or interfacial energy $E_{\text {hkl }}$ can be defined in terms of the work $W_{\text {hkl }}$ needed to separate a homogeneous crystal along a particular crystallographic plane $\left(E_{\mathrm{hkl}}=1 / 2 W_{\mathrm{hkl}}\right)$ or along the interface between two different crystals. Generally, materials with low surface energies, when deposited on high surface energy substrates, will grow in a layer growth mode because

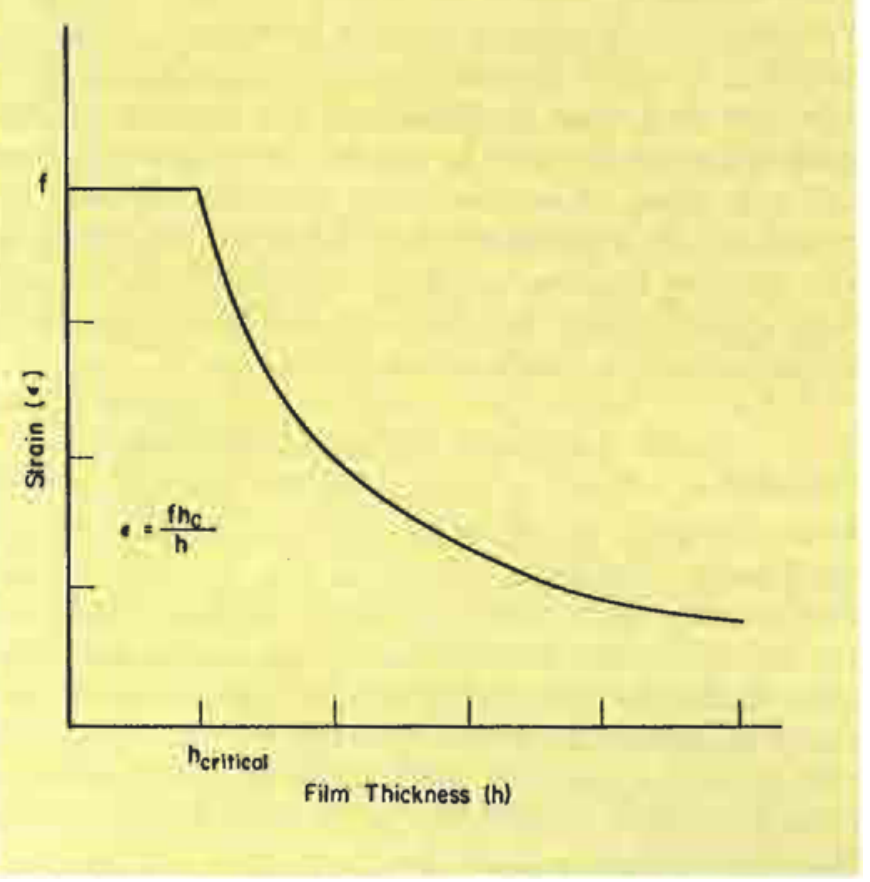

Fig. 2 The relationship between strain in an epitaxial cubic film and its thickness.

the total energy of the system will be reduced. In the reverse case, where a high surface energy material is grown on a low surface energy substrate, island growth is favoured. SK growth is predicted if the conditions for layer growth are complemented by a high lattice strain energy at the interface caused by a large misfit in the lattice parameters, and/or the presence of quite different structures in the two crystals.

\section{Interfacial Strain and Misfit Dislocations}

The strain in a film growing by a layer growth mechanism has been derived (10). Figure 2 illustrates the results. Up to a critical film thickness, $h_{c}$, the strain equals the misfit, which for a simple cubic crystal is given by

$$
f=\left(a_{\mathrm{s}}-a_{\mathrm{f}}\right) / a_{\mathrm{f}}
$$

where $a_{\mathrm{s}}$ and $a_{\mathrm{f}}$ are the unstrained lattice parameters of the substrate and film respectively. Thus positive (negative) $f$ values mean that the film in the interfacial region experiences a tensile (compressive) strain. Generally one assumes a rigid substrate, especially for very thin films. The formula for the curve in Figure 2 for $h>h$ is complicated but shows that the strain decreases as $h^{-1}$. In this same region, misfit 
dislocations are introduced at the interface and they are responsible for the reduced strain. Their function is to localise the misfit strain to the regions of the misfit dislocations, leaving wide areas of good fit in between. As the film thickens, the misfit dislocation density increases, rapidly at first, and then more gradually until the strain in the film goes effectively to zero. In practice, measurements show that this strain elimination takes place in less than approximately 10 monolayers. Such effects are also present at the interface between an island overgrowth and its substrate, but of course the effects are modified by the size of the island and the interfacial area of contact.

\section{Gold-Substrate Epitaxial Systems}

This section will list the various epitaxial systems that have been reported in the literature. Extensive use of two previous listings were made, the earlier one by Gebhardt and Neuhaus (4), which covered systems from 1836 to 1970, and the list by Grunbaum (5) covering systems through July, 1974. In the listing by Gebhardt and Neuhaus the orientation relationships are given, while that by Grunbaum indicates the experimental methods used to study the particular epitaxial systems. In the present list, only the overgrowth $\mathrm{Au}$ ) and substrate material are given along with the references. The first element (A) in the A/B notation is the overgrowth (Au) and the second, $B$, is the substrate. The various systems are listed according to the types of substrates used.

\section{Acknowledgement}

This work was supported in part by a grant from the United States Department of Energy, Basic Energy Sciences Division, on grant number DE-FG02-84ER45139.

\begin{tabular}{ll} 
& \multicolumn{1}{c}{$\begin{array}{c}\text { Table I } \\
\text { Au/Metals }\end{array}$} \\
Substrate & \multicolumn{1}{c}{ References } \\
$\mathrm{Ag}$ & $11-52$ \\
$\mathrm{~A}$ & 53 \\
$\mathrm{Cr}$ & 54,55 \\
$\mathrm{Cu}$ & $12,56-71$ \\
$\mathrm{Cu}{ }_{3} \mathrm{Au}$ & 72 \\
$\mathrm{Fe}$ & $56,57,73$ \\
$\mathrm{Mo}$ & $74-79$ \\
$\mathrm{Ni}$ & 19,80 \\
$\mathrm{~Pb}$ & 81,82 \\
$\mathrm{Pd}$ & $12,19,27,45,50,63,82-92$ \\
$\mathrm{Pt}$ & $12,93-96$ \\
$\mathrm{~W}$ & $65,78,97-104$ \\
$\mathrm{Zn}$ & 105
\end{tabular}

Table II

Au/Selected Semiconductors and Chalcogenides

$\begin{array}{ll}\text { Substrate } & \text { References } \\ \mathrm{C} \text { (graphite) } & 106-110 \\ \mathrm{Ge} & 111,112 \\ \mathrm{Si} & 65,111-125 \\ \mathrm{GaAs} & 126-130 \\ \mathrm{GaSb} & 131-133 \\ \mathrm{MoS}_{2} & 45,82,109,110,134-149 \\ \mathrm{PbS} & 65,150-154 \\ \mathrm{PbSe} & 65,153,155 \\ \mathrm{PbTe} & 65,153 \\ \mathrm{SnTe} & 153 \\ \mathrm{ZnS} & 80\end{array}$

\section{Table III \\ Au/Carbonates, Oxides, Mica}

$\begin{array}{ll}\text { Substrate } & \text { References } \\ \mathrm{CaCO}_{3} & 12,57,156 \\ \mathrm{AlO}_{3} \text { (sapphire) } & 157,158 \\ \mathrm{BaTO}_{2} & 159,160 \\ \mathrm{MgO}^{3} & 45,65,109,110,145,160-174 \\ \mathrm{SiO}_{3} \text { (quartz) } & 11,57,156,160 \\ \mathrm{ZnO}^{\mathrm{M} \delta} & 175,176 \\ \mathrm{Mica} & 12,34,37,57,148,156,160,172, \\ & 177.191\end{array}$

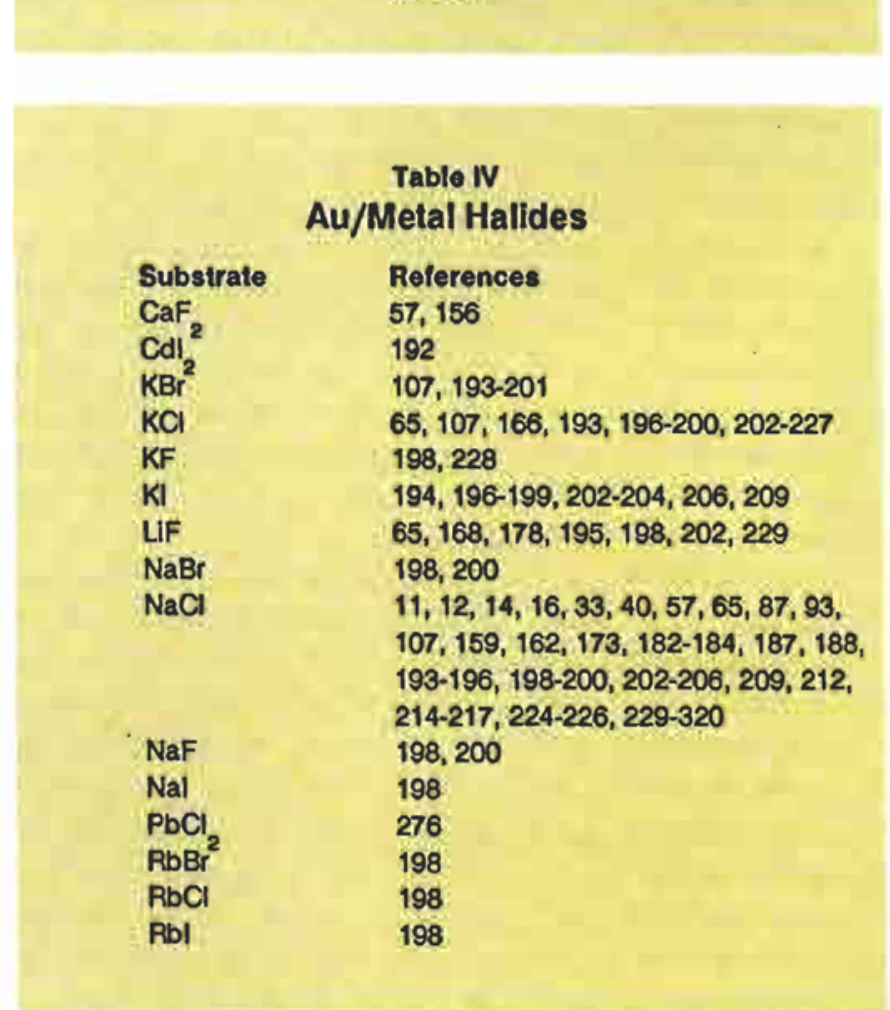




\section{References}

1 J.W.A. Sachtler, M.A. van Hove, J.P. Biberian and G.A. Somorjai, Phys. Rev. Lett., 1980, 45, 1601

2 C.H.F. Peden and D.W. Goodman, J. Catalysis (in Press); J.E. Houston, C.H.F. Peden, D.S. Blair and D.W. Goodman, Surf. Sci., $1986,167,477$

3 G.C. Osbourn, J. Vac. Sci. Technol., 1982, 21, 469

4 M. Gebhardt and A. Neuhaus, 'Epitaxy Data of Inorganic and Organic Crystals', Landolt-Bornstein, 8, K.-H. Hellwege and A.M. Hellwege (eds.), Springer Verlag, Berlin, 1972

5 E. Grunbaum, 'List of Epitaxial Systems', in Epitaxial Growth B, J. W. Matthews (ed.), p. 611, 1975

6 F.S. Frank and J.H. van der Merwe, Proc. R. Soc., 1949, 198A, 205

7 I.N. Stranski and L. Krastanov, Sitzungsber. Akad. Wiss. Wien, Math.-Naturwiss. K1, IIb, 1938, 146, 797

8 M. Volmer and A. Weber, Z. Phys. Chem., 1926, 119, 277

9 R.W. Vook, Intemational Metals Reviews, 1982, 27, 209

10 J.H. van der Merwe, J. Appl. Phys, 1963, 34, 117, 123; Treatise on Materials Science and Technology, H. Herman (ed.), Academic Press, N.Y., 1973, 2, 1

11 L. Brueck, Ann. Phys, 1936, 26, 233

12 J.H. van der Merwe, Discuss. Faraday Soc., 1949, 5, 201

13 R.C. Newman, Philos. Mag., 1957, 2, 750

14 G.A. Bassett and D.W. Pashley, J. Inst. Metals, 1958-59, 87, 449

15 D.R. Brame and T. Evans, Philos. Mag., 1958, 3, 971

16 G.A. Bassett, J.W. Menter and D.W. Pashley, Discuss. Faraday Soc., 1959, 28, 7

17 D.W. Pashley, Philos. Mag., 1959, 4, 324

18 P.W. Palmberg and T.N. Rhodin, Phys. Rev., 1967, 161, 586

19 S. Shirai, Y. Fukuda and M. Nomura, J. Phys. Soc. Japan, 1961, 16, 1989

20 E.W. Dickson and D.W. Pashley, Philos. Mag., 1962, 7, 1315

21 M.H. Jacobs and D.W. Pashley, Proc. Sth Int. Congr. Electron Microscopy, Phila., S.S. Breese, Jr. (ed.), Academic Press, N.Y., 1962, 1, 00-4

22 H. Poppa, Proc. 5th Int. Congr. Electron Microscopy, Phila., S.S. Breese, Jr. (ed.), Academic Press, N.Y., 1962, p. GG-14

23 D.W. Pashley and M.J. Stowell, Philos. Mag., 1963, 8, 1685

24 J.G. Allpress and J.G. Sanders, Philos, Mag., 1964, 9, 645

25 J.R. Smith and H. Saltsburg, J. Chem. Phys., 1964, 40, 3585

26 E.W. Dickson, M.H. Jacobs and D.W. Pashley, Philos. Mag., 1965, 11, 575

27 J.W. Matthews, Philos. Mag., 1966, 13, 1207

28 J.W. Matthews, Physics of Thin Films, G. Hass and R.E. Thun (eds.), Academic Press, N.Y., 1967, 4, 137

29 W.M. Gibson, J.B. Rasmussen, P. Ambrosius-Olesen and C.J. Andreen, Can. J. Phys. 1968, 46, 551

30 D.W. Pashley, Proc. $R$. Soc., 1968, A255, 218

31 F. Zignani, G.F. Missiroli, A. Desalvo and S. Petralia, Nuovo Cimento, 1968, 558, 539

32 S. Datz, C.O. Moak, T.S. Noggle, B.R. Appleton and H.O. Lutz, Phys. Rev., 1969, 179, 315

33 E.R. Dumler and P. Kittl, J. Mater. Sci, 1969, 4, 89

34 H. Jaeger, P.D. Mercer and R.G. Sherwood, Surf. Sci., 1969, 13, 349

35 S.K. Scharma and R.P.S. Kuswaha, Surf. Sci., 1969, 18, 449

36 T. Schober, J. Appl. Phys., 1969, 40, 4658

37 K. Reichelt and H.O. Lutz, J. Cryst. Growth, 1971, 10, 103

38 P.N.S. Dennis and P.J. Dobson, Surf. Sci., 1972, 33, 187
39 I. Dumler and M.R. Marrapodi, Thin Solid Films, 1972, 12, 279

40 G.F. Missiroli, Thin Solid Films, 1972, 12, S35

41 H. Pascard, F. Hoffmann and C. Sella, Thin Solid Films, 1972(A), 12,41

42 J.O.C. Peng, Proc. 30th EMSA, C.J. Arceneaux (ed.), Claitor's, Baton Rouge, La., 1972, p. 634

43 I. Dumler and E. Donoso, Thin Solid Films, 1976, 37, 143

44 F. Soria, J.L. Sacedon, P.M. Echenique and D. Titterington, Surf. Sci., 1977, 68, 448

45 K. Yagi, K. Takayanagi, K. Kobayashi, N. Osakabe, Y. Tanishiro and G. Honjo, Surf. Sci., 1979, 86, 174

46 L.C. Feldman, Nucl. Inst. Methods Phys. Res., 1981, 191, 211

47 C. Ammer, M. Klaua and H. Bethge, Phys. Status Solidi, 1982, 71A, 415

48 L.C. Feldman, R.J. Culbertson and P.J. Sitverman, J. Vac. Sci. Technol, 1982, 20, 368

49 A.H. King, Phys. Status Solidi, 1983, 76, 629

50 R.C. Jaklevic, Phys. Rev., 1984, 30B, 5494

51 A.P. Shapiro and T.C. Chiang, Phys. Rev., 1985, 31B, 2541

52 K. Yagi, K. Kobayashi, Y. Tanishiro and K. Takayanagi, Thin Solid Films, 1985, 126, 95

53 W.F. Egelhoff, J. Vac. Sci. Technol., 1982, 20, 668

54 O.S. Heavens and L.E. Collins, J. Phys. Radium, 19S2, 13, 658

55 M.B. Brodsky, P. Marikar, R.J. Friddle, L. Singer and C.H. Sowers, Solid State Comm., 1982, 42, 453

S6 G.I. Finch, H. Wilman and L. Yang, Discuss. Faraday Soc., 1947, A43, 144

57 A. Neuhaus, Fortshr. Mineral, 1950/51, 29/30, 136

58 H. Wilman and M.S.A. Khan, Union Intern. de Cryst. 3rd Congr. Paris, 1954

59 O. Haase, Z. Naturforsch, 1956, 11a, 862

60 L.P. Lafourcade, P. Larroque and N. Quatti, C.R. Acad. Sci., 1959, 249, 230

61 Q.T. Nguyen, J.J. Couderc and M.F. Pilod, Proc, 2nd Eur. Reg. Conf. Electron Microscopy, Delft, A.L. Houwink and B.J. Spit (eds.), De Nederlandse Verenigung Voor Electronmicroscopie, Delft, 1960, 1, 289

62 K.R. Lawless, J. Vac. Sci. and Technol., 1965, 2, 24

63 P.W. Palmberg and T.N. Rhodin, J. Phys. Chem. 1968, 49, 134

64 E.R. Thompson and K.R. Lawless, Electrochim. Acta., 1969, 14, 269

65 E. Bauer and $H$. Poppa, Thin Solid Films, 1972, 12, 167

66 J.E. Macur and R.W. Vook, Proc. 32nd Ann. Electron Microscopy Soc. Amer, C.J. Arceneaux, (ed.), Claitor's, Baton Rouge, La., 1974, p. 482

67 R.W. Vook, C.T. Horng and J.E. Macur, J. Cryst. Growth, 1975, 31, 353

68 R.W. Vook and J.E. Macur, Thin Solid Films, 1976, 32, 199

69 J.E. Macur and R.W. Vook, Proc. 37th Ann. Electron Microscopy Soc. Amer, G.W. Bailey (ed.), 1979, 462

70 J.E. Macur and R.W. Vook, Thin Solid Films, 1980, 66, 371

71 J.E. Macur and R.W. Vook, Thin Solid Films, 1980, 66, 311

72 M.J. Marcinkowski, A.J. Baker and RM. Fisher, Phys. Status Solidi, 1972, A12, 431

73 S. Ohmiya, J. Echigoya and M. Nemeto, Trans. Japan. Inst. Met., 1978, 19, 18

74 C.W. Price, Proc. 31st Ann. Electron Microscopy Soc. Amer., C.J. Arceneaux (ed.), Claitor's Baton Rouge, La., 1973, p.38

75 E. Gillet and B. Gruzza, Surf. Sci, 1980, 97, 553

76 E. Gillet and B. Gruzza, Proc. 4th Int. Conf. on Solid Surf., Cannes, Societe Francaise du Vide, 1980, 1, 699

77 B. Gruzza and E. Gillet, Thin Solid Films, 1980, 68, 345 
78 E. Bauer and H. Poppa, Thin Solid Films, 1984, 121, 159

79 A. Pavlovska, M. Paunov and E. Bauer, Thin Solid Films, 1985, 126, 129

80 M. Kubo and S. Miyake, J. Phys. Soc. Japan, 1948, 3, 114

81 K. Takayanagi, Ultramicroscopy, 1982, 8, 145

82 K. Yagi, K. Kobayashi, Y. Tanishiro and K. Takayanagi, Thin Solid Films, 1985, 126, 95

83 H. Poppa, Z. Naturforsch, 1964, 19A, 835

84 K. Yagi, K. Kobayashi, K. Takayanagi and G. Honjo, Proc. 7th Int. Congr. Electron Microscopy, Grenoble, P. Favard (ed.), Societe Francaise Microscopie Electronique, Paris, 1970, 2, 439

85 K. Yagi, K. Takayanagi, K. Kobayashi and G. Honjo, J. Cryst. Growth, 1971, 9,84

86 J.W. Matthews, Thin Solid Films, 1975, 26, 129

87 J. Koshy, Thin Solid Films, 1976, 38, 337

88 F. Hila and M. Gillet, Thin Solid Films, 1982, 87, L7

89 Y, Kuk, L.C. Feldman, P.J. Silverman, Phys. Rev. Lett., 1983, 50, 511

90 Y. Kuk, L.C. Feldman and P.J. Silverman, J, Vac. Sci. Technol., 1983, 1A, 1060

91 J. Woltersdorf and E. Pippel, Thin Solid Films, 1984, 116, 77

92 Y. Takahashi and M. Shimizu, J. Phys. F., 1985, 15, L71

93 V.S. Postnikov, V.M. Ievlev and K.S. Solov'ev, Sov. Phys.Crystallogr,, 1976, 21, 226

94 J.W.A. Sachtler, M.A. Van Hove, J.P. Biberian and G.A. Somorjai, Sırf. Sci., 1981, 110, 19

95 J.W.A. Sachtler, J.P. Biberian and G.A. Somorjai, Strf. Sci., 1981, 110, 43

96 S. Ferrer, M. Salmeron, C. Ocal, P. Roubin and J. Lecante, Surf. Sci., 1986, 160, 488

97 H.M. Montagu-Pollock, T.H. Rhodin and N.J. Southon, Surf. Sci., $1968,12,1$

98 A. Cetronio and J.P. Jones, Surf. Sci, 1973, 40, 227

99 P.D. Augustus, J.P. Jones, Surf. Sci., 1977, 64, 713

100 E. Bauer, H. Poppa, G. Todd and P.R. Davis, J. Appl. Phys., 1977, 48,3773

101 L.A. Bruce and H. Jaeger, Philos. Mag., 1978, 37, 337

102 J.P. Jones and C. Patel, Surf. Sci., 1979, 80, 265

103 J. Kolaczkicwicz and E. Bauer, Phys. Rev. Lett., 1984, 53, 485

104 E. Bauer and H. Poppa, Thin Solid Films, 1985, 121, 159

105 J.J. Couderc, J. Garigue, L. LaFourcade and T.Q. Nguyen, C.R. Acad.Sci., 1959, 249, 2037

106 R. Hocart and A. Oberlin, C.R. Acad. Sci., 1954, 239, 1228

107 P. Conjeaud and Cl. Sella, C.R. Acad. Sci., 1959, 248, 1680

108 J.B. Darby and C.H. Wayman, Phys. Status Solidi, 1970, A1, 729

109 G. Honjo, K. Takayanagi, K. Kobayashi and K. Yagi, Phys. Status Solidi, 1979, 55A, 353

110 Y. Tanishiro, H. Kanamori, K. Takayanagi, K. Yagi and G. Honjo, Surf. Sci., 1981, 111, 395

111 G. LeLay, G. Quentel, J.P. Faurie and A. Masson, Thin Solid Films, 1976, 35, 273

112 G. Lel ay, G. Quentel, J.P. Faurie and A. Masson, Thin Solid Films, 1976, 35, 289

113 A. Masson and R. Kern, J. Cryst. Growth, 1968, 2, 227

114 T. Narusawa and S. Komiya, Appl. Phys. Lett., 1973, 22, 389

115 W. Fischer and P. Wissmann, Z. Naturforsch., 1976, 31A, 183

116 W. Fischer and P. Wissmann, Z. Naturforsch, 1976, 31A, 190

117 G. LeL Lay and J.P. Faurie, Surf. Sci., 1977, 69, 295

118 N. Osakabe, Y. Tanishiro, K. Yagi and G. Honjo, Surf. Sci., 1980, 97, 393

119 A. Cros, J. Derrien, C. Mouttet, J.P. Gaspard, P. Lambin and F. Salvan, J. Phys. Colloq., 1980, 41, 795
120 A.K. Green and E. Bauer, J. Appl, Phys, 1981, 52, 5098

121 V.G. Lifshits, V.B. Akilov and Y.L. Gavriljuk, Solid State Comm., 1981, 40, 429

122 A. Cros, F. Houzay, G.M. Guichar and R. Pinchaux, Surf. Sci., 1982, 116, L232

123 L.J. Brillson, A.D. Katnani, M. Kelly and G. Margaritondo, J. Vac. Sci. Technol., 1984, 2A, 551

124 T. Ito and W.M. Gibson, J. Vac. Sci. Technol., 1984, 2A, 561

125 S.A. Chambers, T.R. Greenlee, G.A. Howell and J.H. Weaver, J. Vac. Sci. Technol., 1985, 3A, 1291

126 J.S. Vermaak and L.W. Snyman, F.D. Auret, J. Cryst. Growth, 1978, 42, 132

127 S. Leung, A.G. Milnes and D.D.L. Chung, Thin Solid Films, 1983, 104, 109

128 T. Yoshiie, C.L. Bauer and A.G. Milnes, Thin Solid Film., 1984, 111, 149

129 D.D. Chung and E. Beam III, Thin Solid Films, 1985, 128, 299

130 E. Beam III and D.D. Chung, Thin Solid Films, 1985, 128, 321

131 N. Koshizaki, M. Kudo, M. Owari, Y. Nikei and H. Yamada, Japan. J. Appl. Phys., 1980, 19, L349

132 J.R. Lince and R.S. Williams, J. Vac. Sci., Technol., 1985, B3, 1217

133 J.R. Lince and R.S. Williams, Thin Solid Films, 1986, 137, 251

134 Y. Kainuma, J. Phys. Soc. Japan, 1951, 6, 185

135 J.C. Tribollet, Thesis, University of Toulouse, 1965

136 D.W. Pashley, M.J. Stowell and M.H. Jacobs, T.J. Law, Philos. Mag., 1964, 10, 127

137 M.H. Jacobs and M.J. Stowell, Philos. Mag., 1965, 11, 591

138 M.H. Jacobs, D.W, Pashley and M.J. Stowell, Philos, Mag., 1966, 13,129

139 D.W. Pashley and M.J. Stowell, J. Vac. Sci. Technol, 1966, 3, 156; Proc. 6th Int. Congr. Electron Microscopy, Kyoto, 1966, R. Uyeda (ed.), Maruzen, Tokyo, 1966, 1, 487

140 M.J. Stowell and T.J. Law, Phys. Status Solidi, 1966, 16, 117

141 W.A. Jesser and D. Kuhlmann-Wilsdorf, J. Appl. Phys., 1967, 38, 5128

142 M.S. Khidr, P. Ignacz and J.F. Pocza, Proc. 2nd Coll. Thin Films, Budapest 1967, Hungarian Acad, Sci., Budapest 1968, p. 45

143 W.A. Jesser and D. Kuhlmann-Wilsdorf, Acta. Met., 1968, 16, 1325

144 M.J. Stowell and T.J. Law, Phys. Status Solidi, 1968, 25, 139

145 G. Honjo and K, Yagi, J. Vacumm Sci. and Technol, 1969, 6, 576

146 M.J. Stowell, 'Molecular Processes on Solid Surfaces', Proc, 3rd Battelle Inst. Materials Science Coll., Kronberg, Germany, 1968, E. Drauglis, R.D. Gretz and R.I. Jaffee (eds.), McGraw Hill, N.Y., 1969, p. 461

147 U. Valdre, E.A. Robinson, D.W. Pashley, M.J. Stowell and T.J. Law, J. Phys. E-Sci. Instr., 1970, 3, S01

148 J.W. Matthews, Surf. Sci, 1972, 31, 241

149 K. Yagi, Proc. 38th Ann. Electron. Microscopy. Soc. Amer., G.W. Bailey (ed.), Claitor's, Baton Rouge, La,, 1980, p. 290

150 T. Hanawa and K. Takeda, Appl. Phys. Lett., 1969, 15, 360

151 A.K. Green, C. Dancy and E. Bawer, J. Vac. Sci. Technol., 1971, 8, 165

152 K. Heinemann and H. Poppa, Appl. Phys. Lett., 1972, 20, 122

153 A.K. Green, J. Dancy and E. Bauer, J. Vac. Sci. Technol., 1973, 10, 494

154 M.H.B. Stiddard, Thin Solid Fims, 1981, 82, 337

155 H. Poppa, R.D. Moorhead and K. Heinemann, J. Vac. Sci. Technol., 1974, 11, 132

156 O. Ruediger, Ann. Physik, 1937, 30, 505

157 V.P. Vlasov, Y.M. Gerasimov and G.I. Distler, Soviet Phys.-Cryst. (English Transl.), 1970, 15, 289 

Sci., 1976, 12, 577

159 K.L. Chopra, J. Appl. Phys., 1966, 37, 3405; Proc. 6th Int. Congr. Electron Microscopy, Kyoto, 1966, R. Uyeda (ed.), Maruzen, Tokyo, 1966, 1, 519

160 K.L. Chopra, J. Appl. Phys., 1969, 40, 906

161 V.F.G. Tull, Proc. R. Soc., 1951, 206A, 219

162 D.A. Brine and R.A. Young, Philos. Mag., 1963, 8, 651

163 P.W. Palmberg, T.N. Rhodin, Phys. Rev., 1967, 161, 586

164 P.W. Palmberg, T.N. Rhodin and C.J. Todd, Appl. Phys. Lett., 1967, 11, 33; Proc. 4th Int. Vac. Congr., Manchester 1968, Inst. Physics Conf. Ser. 6, London, 1968, p. 515

165 K.L. Chopra, Phys. Status Solidi, 1969, 32, 489

166 T.N. Rhodin, P.W. Palmberg and C.J. Todd, 'Molecular Processes on Solid Surfaces', Proc. 3rd Battelle Inst. Materials Sci. Coll. Kronberg. Germany, 1968, E. Drauglis, R.D. Gretz and R.I. Jafee (eds.), McGraw-Hill, N.Y., 1968, p. 499

167 H. Sato, S. Shinozaki and L.J. Cicotte, J. Vac. Sci. Technol., 1969, 6, 62

168 A.K. Green, J. Dancy and E. Baucr, J. Vac. Sci. Technol, 1970, 7, 159

169 H. Sato and S. Shinozaki, Surf. Sci, 1970, 22, 229

170 H. Sato and S. Shinozaki, J. Vac. Sci. Technol., 1971, 8, 159

171 R.D. Moorhead and H. Poppa, Proc. 30th Ann. Electron Microscopy Soc. Amer., Los Angcles, CA 1972, C.J. Arceneaux, (ed.), Claitor's, Baton Rouge, La., 1972, p. 516

172 H. Poppa, R.D. Moorhead and K. Heinemann, Nucl. Instr. Meth., $1972,102,521$

173 R. Ueda and T.E. Hutchinson, Thin Solid Films, 1976, 39, 25

174 Y. Shigeta and K. Maki, Japan. J. Appl. Phys., 1979, 18, 71

175 E.F. Wasserman and K.A. Polacek, Appl. Phys, Lett., 1970, 16, 259

176 E.F. Wasserman and K.A. Polacek, Surf. Sci., 1971, 28, 77

177 F. Kirchner and O. Rudiger, Ann. Phys. (Leipzig), 1937, 30, 609

178 M.J. Hall and M.W. Thompson, Brit. J. Appl. Phys, , 1961, 12, 495

179 K.L. Chopra, L.C. Bobb and M.H. Francombe, J. Appl. Phys., 1963, 34, 1699

180 K.L. Chopra and L.C. Bobb, Single Crystal Films, M.H. Francombe and H. Sato (eds.), Pergamon Press, Oxford 1964, p. 373

181 R.L. Hines, J. Physique, 1964, 25, 134

182 R.F. Adamsky and R.E. Leblanc, J. Vac. Sci. Technol., 1965, 2, 79

183 K.L. Chopra, Appl. Phys. Lett., 1965, 7, 140

184 R.F. Adamsky, The Use of Thin Films in Physical Investigations, NATO Advanced Study Inst., 1965, J.C. Anderson (ed.), Academic Press, NY, 1966, p. 243

185 J.G. Allpress, H. Jaeger, P.D. Mercer and J.V. Sanders, Proc, 6th Int. Congr. Electron Microscopy Kyoto, 1966, R. Uyeda (ed.), Maruzen, Tokyo, 1966, 1, 489

186 J.G. Allpress and J.V. Sanders, Surf. Sci, 1967, 7, 1

187 M. Fukamachi, S. Nagakura and S. Oketani, Acta Met., 1967, 15, 1402

188 R.S. Nelson, Philos. Mag., 1967, 15, 845

189 H. Poppa, K. Heinemann and A.G. Elliot, J. Vac. Sci. Technol., $1971,8,471$

190 Y. Nakajima and K. Kinosita, Japan. J. Appl. Phys., 1974, suppl. 2 (1), p. 575

191 J. Cardoso and M. Harsdorff, Z. Naturforsch., 1978, 33a, 442

192 A. Persson, C.E. Blomquist and H. Norden, K. Svenska Vet. Akad. F. Fys., 1967, 35, 129

193 P. Conjeaud, C.R. Acad. Sci., 1959, 248, 566

194 R.W. Adam, Z. Naturforsch., 1966, 21A, 497
195 M. Gillet and E. Gillet, Proc. 6th Int. Congr, Electron Microscopy, Kyoto, 1966, R. Uyeda (ed.), Maruzen, Tokyo, 1966, 1, 633

196 R.W. Adam, Z. Naturforsch., 1968, 23A, 1526

197 T. Kato, Japan. J. Appl. Phys., 1968, 7, 1162

198 W.A. Jesser and J.W. Matthews, J. Cryst. Growth, 1969, 5, 83

199 M. Harsdorff, R.W. Adam and H. Schmeisser, Kristall und Tecimik, 1970, 5, 279

200 J.R. Roos and J.S. Verm . J. Cryst. Growth, 1972, 13/14, 217

201 A. Puskeppel and M. Ha, ff, Thin Solid Films, 1976, 35, 99

202 H. Gottsche, Z. Naturforsch., . 556, 11a, 55

203 M. Harsdorf, Fortschr. Mineral., 1964, 42, 250

204 E. Bauer, A.K. Green and K.M. Kunz, App. Phys. Lett., 1966, 8, 248

205 S. Ino and S. Ogawa, Proc. 6th Int. Cong. Electron Microscopy, Kyoto, 1966, R. Uyeda (ed.), Maruzen, Tokyo, 1966, 1, 521; J. Phys. Soc. Japan, 1966, 22, 1365

206 K.M. Kunz, A.K. Green and E. Bauer, Phys. Status Solidi, 1966, 18, 441

207 S. Ogawa, S. Ino, T. Kato and H. Ota, J. Phys. Soc. Japan, 1966, 21 1963

208 P.W. Palmberg, T.N. Rhodin and C.J. Todd, Appl. Phys. Lett., 1967, 10,122

209 M. Harsdorff, Z. Naturforsch, 1968, 23A, 1059

210 A. Masson, J.J. Metois and R. Kern, C.R. Acad. Sci., 1968, 267B, 64; J. Cryst. Growth, 1968, 34, 196

211 P.W. Palmberg, C.J. Todd and T.N. Rhodin, J. Appl. Phys., 1968, 39, 4650

212 H. Bethge, J. Vac. Sci. Technol., 1969, 6, 460

213 C.A.O. Henning, Surf. Sci, 1969, 12, 308

214 C.A.O. Henning, J.C. Lombard and J.C. Botha, Appl. Phys. Lett., $1969,14,109$

215 S. Ogawa and S. Ino, J. Vacuum Sci. Technol, 1969, 6, 527

216 C.A.O. Henning, Nature, 1970, 227, 1129

217 C.A.O. Henning and J.S. Vermaak, Philos. Mag., 1970, 22, 281

218 A. Masson, J.J. Metois and R. Kern, C.R. Acad. Sci., 271B, 235, 298

219 R. Kern, A. Masson and J.J. Metois, Surf. Sci., 1971, 27, 483

220 A. Masson, J.J. Metois and R. Kern, Surf. Sci., 1971, 27, 463

221 A. Masson, J.J. Metois and R. Kern, Advances in Epitaxy and Endotaxy, H.G. Schneider, (ed.), 1971, 2, 103, VEB Deutscher Verlag für Grundstoffindustrie, Leipzig.

222 J.J. Metrois, M. Gauch, A. Masson and R. Kern, Thin Solid Films, $1972,11,205$

223 J.J. Metois, Surf. Sci., 1973, 36, 269

224 C.J. Rossow, I.A. Kotze and C.A.O. Henning, Thin Solid Films, $1975,29,71$

225 M.1. Birjega, N. Popescu-Popgrion and V. Topa, Thin Solid Films, $1982,94,67$.

226 P.S. Schabes-Retchkiman and M.J. Yacaman, Appl. Surf. Sci., 1982, 11, 149

227 B.G. Atabev, E.M. Dubinina, S.A. Elovikov and G.P. Netishenskaya, Bull. Acad. Sci., USSR, Phys. Ser., 1984, 48, 1

228 D.J. Stirland, Appl. Phys. Lett., 1969, 15, 88

229 G. Honjo, Single Crystal Films, M.H. Francombe and H. Sato (eds.), Pergamon Press, Oxford, 1964, p. 189

230 S. Shirai, Proc, Phys.-Math. Soc. Japan, 1943, 25, 168

231 M. Miwa and S. Annaka, J. Phys. Soc. Japan, 1954, 9, 302

232 S. Ogawa, D. Watanabe and F.E. Fujita, J. Phys. Soc. Japan, 1955, 10,429

233 J.J. Trillat, N. Terao, L. Tertian and H. Gervais, C.R. Acad. Sci, $1955,240,1557$

234 A. Oberlin and R. Hocart, Int. Union Cryst. Symposium, 1956, 4, 2. 
235 R.B. Kehoe, Philos. Mag., 1957, 2, 455

232 J.W. Matthews, Philos. Mag., 1959, 4, 1017

237 A. Nagasawa and S. Ogawa, J. Phys. Soc. Japan, 1960, 15, 1421

238 M. Hucher, Bull. Soc. Franc. Mineral. Crist, 1962, 85, 5

239 S. Ino, D. Watanabe and S. Ogawa, J. Phys. Soc. Japan, 1962, 17, 1074

240 I.I. Papirov and L.S. Palatnik, Soviet Phys.-Cryst. (English Transl.), $1962,7,222$

241 R.F. Adamsky, and R.E. Leblanc, Trans. 10th Nat. Vac. Symp. Amer, Vac. Soc, Boston, 1963, G.H. Bancroft (ed.), MacMillan, N.Y. 1963, p. 453

242 D.S. Campbell and D.J. Stirland, Philos. Mag., 1964, 9, 703

243 M.H. Francombe and M. Schlachter, The Use of Thin Films in Physical Investigations, Nato Advanced Study Inst., 1965, J.C. Anderson (ed.), Academic Press, N.Y., 1966, p. 29

244 S. Ino, D. Watanabe and S. Ogawa, J. Phys. Soc. Japan, 1964, 19, 881

245 J. Jaunet and C. Sella, Bull. Soc. Franc. Mineral. Crist., 1964, 87, 393

246 L.E. Murr, Brit. J. Appl. Phys., 1964, 15, 1511

247 J.W. Matthews and E. Grunbaum, Appl. Phys. Letters, 1964, 5, 106

248 C. Sella and J.J. Trillat, Single Crystal Films, M.H. Francombe and H. Sato (eds.), Oxford, Pergamon Press, 1964, p. 201

249 E. Grunbaum and J.W. Matthews, Phys. Status Solidi, 1965, 9, 731

250 J.W. Matthews, Philos. Mag., 1965, 12, 1143

251 J.W. Matthews, Appl. Phys. Lett., 1965, 7, 131

252 J.W. Matthews, Philos. Mag., 1965, 11, 1233

253 H. Schlotter, Z. Naturforsch., 1965, 20A, 1201

254 E. Gillet and M. Gillet, C.R. Acad. Sci, 1966, 262B, 35

255 C.A.O. Henning, Solid St. Comm., 1966, 4, 439

256 S. Ino, J. Phys. Soc. Japan, 1966, 21, 346

257 J.W. Matthews, J. Vac. Soc. Technol., 1966, 3, 133

258 K. Mihama and H. Aoe, Proc. 6ih Int. Congr. Electron Microscopy, Kyoto, 1966, R. Uyeda (ed.), Maruzen, Tokyo, 1966, 1, 523

259 K. Mihama and Y. Yasuda, J. Phys. Soc. Japan, 1966, 21, 1166

260 L.E. Murr and M.C. Inman, Philos. Mag., 1966, 14, 135

261 D.J. Stirland, Appl. Phys. Lett., 1966, 8, 326

262 RA. Connell, J. Appl. Phys., 1967, 38, 2397

263 S. Ino and S. Ogawa, J. Phys. Soc. Japan, 1967, 22, 1365

264 K. Mihama, H. Miyahara and H. Aoe, J. Phys. Sac. Japan, 1967, 23, 785

265 D.J. Stirland, Thin Solid Films, 1967/68, 1, 447

266 A. Catlin, W.P. Walker and K.R. Lawless, Acta, Met., 1968, 8, 734

267 L.T. Chadderton and M.G. Anderson, Thin Films, 1968, 1, 229

268 Y.M. Gerasimov and G.I. Distler, Naturwissenschaften, 1968, 55, 132

269 M. Hardsdorff, Z. Naturforsch, 1968, 23A, 1253

270 C.A.O. Henning, Surf. Sci., 1968, 9, 277, 296

271 T. Inuzuka and R. Uyeda, Appl. Phys. Lett., 1968, 13, 3

272 T. Inuzuka and R. Uyeda, J. Phys, Soc. Japan, 1968, 25, 1299

273 T. Komoda, Japan. J. Appl. Phys., 1968, 7, 27

274 S. Maruyama and H. Kiho, J. Phys. Soc. Japan, 1968, 25, 1392

275 K. Mihama and M. Tanaka, J. Cryst. Growth, 1968, 2, 51

276 L.S. Palatnik, V.M. Kosevitsch and A.A. Sokol, Proc. 4th Eur. Reg. Conf. Electron Microscopy, Rome, 1968, D.S. Bocciarelli (ed.), Tipografia Poliglotta Vaticana, Rome, 1968, 1, 401

277 R.S. Toth and L.J. Cicotte, Thin Solid Films, 1968, 2, 111

278 R. Ueda and T. Inuzuka, J. Cryst. Growth, 1968, 3, 4, 191

279 E: Gillet and M. Gillet, Thin Solid Films, 1969, 4, 171

280 A. Green, E. Bauer and J. Dancy, 'Molecular Processes on Solid Surfaces', Proc. 3rd Battelle Inst. Materials Sci. Coll, Kronberg,
Germany, 1968, E. Drauglis, R.D. Gretz and R.I. Jaffee (eds.) McGraw-Hill, N.Y., 1969, p. 479

281 C.A.O. Henning and J.S. Vermaak, Appl. Phys. Lett., 1969, 15, 3

282 S. Ino, J. Phys. Soc. Japan, 1962, 26, 1559, 27, 941

283 K. Mihama, J. Vac. Sci. Technol., 1969, 6, 488

284 A.A. Sokol and V.M. Kosevich, Kristallografiya (USSR), 1969, 14, 527

285 K. Hayek and V. Schwabe, Surf. Sci., 1970, 19, 329

286 B. Lewis and M.R. Jordan, Thin Solid Films, 1968, 6, 1

287 H. Sato and S. Shinozaki, J. Appl. Phys., 1970, 41, 3165

288 S.K. Sharma, Thin Solid Films, 1970, 6, 17

289 J.S. Vermaak and C.A.O. Henning, Philos. Mag., 1970, 22, 269

290 G.I. Distler, V.N. Lebedeva and V.V. Moskvin, J. Cryst. Growth, $1971,9,98$

291 R. Ueda and T. Inuzuka, J. Cryst. Growth, 1971, 9, 79

292 M.I. Birjega, F. Glodeamu, N.G. Popescu-Pogrion, I.A. Teodorescu and V. Topa, Thin Solid Films, 1972, 18, 307

293 A.J. Donohoe and J.L. Robins, J. Cryst. Growth, 1972, 17, 70

294 F.A. Koch, C.T. Horng and R.W. Vook, J. Vac. Sci. Technol., 1972, 9,511

295 Y. Murayama, Thin Solid Films, 1972, 12, 287

296 T.S. Noggle, 2nd Nat. Conf. Cryst. Growth, Princeton, N.J., Amer. Assoc. Crystal Growth, 1972, p. 6

297 S. Ogawa and S. Ino, J. Cryst. Growth, 1972, 13/14, 48

298 M. Paunov and M. Hardsdorff, $Z$. Naturforsch, 1972, 27A, 1381

299 M.C. Quintana and J.L. Sacedon, Thin Solid Films, 1972, 14, 149

300 V.I. Trofimov and A.E. Gorodetskii, Sov. Phys.- Solid State, 1972, 14,760

301 M.F. Esteban and J.N. Rojo, Thin Solid Films, 1973, 15, S7

302 E. Gillet and M. Gillet, Thin Solid Films, 1973, 15, 249

303 M.C. Quintana and J.L. Sacedon, Thin Solid Films, 1973, 17, 311

304 M.C. Quintana, J.L. Sacedon, J. Mendiola, Thin Solid Films, 1973, 17, 319

305 J.C. Lombaard, I.A. Kotze and C.A.O. Henning, Solid St. Comm. 1974, 14, 217

306 W.R. Wagner, Surf. Sci., 1974, 41, 291

307 D.L. Kirk and R.M. Innes, Thin Solid Films, 1975, 28, 243

308 V.E. Obukhov, E.I. Tochitskii and N.K. Zherebilo, Sov. Phys.Solid State, 1977, 19, 569

309 M. Jose Yacaman and R.W. Vook, Proc, 35th Ann. Electron Microscopy Soc. Amer, G.W. Bailey (ed.), Claitor's, Baton Rouge, La., 1977, p. 258

310 Yu. V. Bykov, M.B. Guseva, Kh. Kevedo and D. Kh. Adbrashitova Bull. Acad. Sci. USSR, Phys., 1978, 41, 135

311 U. Koster, D.R. Campbell and K.N. Tu, Thin Solid Films, 1978, 53, 129

312 J.N. Orcheson, F.W. Boswell, J.M. Corbett and C.A.O. Henning, Thin Solid Films, 1978, 51, 395

313 W. Klein and H. Hubner, Z. Naturforsch., 1979, 34a, 1196

314 G. Shimaoka, Surf. Sci., 1979, 86, 182

315 H.D. Velfe, H. Stenzel and M. Krohn, Thin Solid Films, 1982, 98, 115

316 M. Krohn, K.P. Meyer and H. Bethge, J. Cryst. Growth, 1983, 64, 326

317 R. Scholz and C.L. Bauer, Scripta Met, 1984, 18, 411

318 M. Harsdorff and W. Jark, Thin Solid Films, 1985, 128, 79

319 R.A. Outlaw and J.H. Heinbockel, J. Vac. Sci. Technol., 1985, 3A, 820

320 K.R. Milkove and S.L. Sass, Proc. Mater. Res. Soc. Symp., Boston, Nov. 1984, Mater. Res. Soc., Pittsburgh, 1985, p. 83 